\title{
Specialisation in pollen collection, pollination interactions and phenotypic variation of the oil-collecting bee Chalepogenus cocuccii
}

\author{
Constanza C. Maubecin, Lourdes Boero, Alicia N. Sérsic \\ Laboratorio de Ecología Evolutiva y Biología Floral, Instituto Multidisciplinario de Biología Vegetal, CONICET, \\ FCEFyN, Universidad Nacional de Córdoba, Córdoba, Argentina
}

Received 18 June 2019 - Revised 27 January 2020 - Accepted 26 February 2020

\begin{abstract}
Bee pollen gathering from a few related plant species is a specialisation known as oligolecty. Although it is an extended phenomenon, it has been scarcely explored in oil-collecting bees. At the geographic level, there is little information about oligolecty persistence and also about phenotypic variation of bees related with abiotic factors. We studied the pollen collection specialisation of the oil-collecting bee Chalepogenus cocuccii, its pollination interactions and phenotypic variation across its distribution range, by analyses of pollen loads, field observations and morphometric measurements. Observations and pollen analyses showed that across its distribution range, C. cocuccii preferred Nierembergia flowers not only for oil but also for pollen. We found two beemorphotypes, though phenotypic variation was not related to abiotic variables. We postulate that $C$. cocuccii is a narrowly oligolectic species, phenotypically and ecologically specialised in Nierembergia.
\end{abstract}

oil-collecting bees / oligolecty / specialisation / pollination interactions / phenotypic variation

\section{INTRODUCTION}

Since Vogel's first discoveries in the 70s, oilcollecting bees and oil-producing flowers have received increased attention and research, and several aspects related to these bees have been described, as nesting and foraging behaviour, oil-collecting structures, phylogenetic relationships among others (recently revised in Possobom and Machado 2017; Neff and Simpson 2017). Most studies related to the interaction between oil-bees and oil-flowers were per-

Electronic supplementary material The online version of this article (https://doi.org/10.1007/s13592-020-00755-4) contains supplementary material, which is available to authorized users.

Corresponding author: C. Maubecin, cmaubecin@gmail.com

Manuscript editor: Klaus Hartfelder formed from the scope of the oil-producing plant species. Some of them focused mainly on variation of floral traits according to their pollinators, while others explored phenotypic variation, pollinators assemblage composition and the influence of abiotic factors on floral phenotype from a geographic perspective (Cosacov et al. 2008; Nattero et al. 2010; Cosacov et al. 2013; Giannini et al. 2013; Ferreiro et al. 2015, 2017; Carneiro et al. 2015; Espíndola and Pliscoff 2019; Maubecin 2019). However, despite those approaches, the ecology and interactions of many oil-bee species remain unknown, and in particular, little is known about the specialisation in pollen collection and phenotypic variation in this singular group of bees.

Besides being a lipidic source, oil-producing flowers may also be a source of pollen for this kind of bees (Vinson and Frankie 1988; Cocucci and Vogel 2001; Cunha and Blochtein 2003; 
Gaglianone 2005; Rego et al. 2006; Alves-dosSantos et al. 2007; Ribeiro et al. 2008). Pollen hosts choice is a key aspect in understanding ecological processes behind bee interactions. According to the quantity of pollen sources, bees can be classified as monolectic, oligolectic or polylectic, depending on whether they use a single host, few related hosts or many host taxa, respectively (Cane and Sipes 2006). Oligolectic solitary bee species use a restricted subset of host plant breath available through time across their geographic range (Cane and Sipes 2006), a common phenomenon among nectar-seeking bees. Oilbees have been traditionally categorised as specialised in collecting oils (Simpson and Neff 1981; Buchmann 1987), but the specialisation in pollen collection has been little explored. We expect that, across its distribution range, solitary oilcollecting bees prefer to gather both pollen and oils from the same floral source, given that this would reduce the energetic costs and the time spent in resources collection rounds. In most studies of floral resources of oil-collecting bees, there is no information about pollen hosts but evidence for and against this hypothesis can be traced in few studies. It was observed, for example, that females of Macropis nuda collect oil and pollen from only one plant species (Cane et al. 1983) while females of some Centris species may collect oils, pollen and nectar from the same or different floral sources (Sérsic and Cocucci 1999; Aguiar 2003; Alves-dos-Santos et al. 2007). Particularly, within the Tapinotaspidini tribe, the extent of oligolecty is poorly known (Neff and Simpson 2017). Therefore, more work is needed to corroborate the specialisation in the pollen collection by the oil-collecting bees.

Geographic phenotypic variation of oilcollecting bees has been also scarcely explored (but see Cosacov et al. 2013; Murúa and Espíndola 2015). It has been reported that pollinator traits directly involved in the oil-plant/oilbee interaction can covary with specific floral traits, specifically in traits related to mechanical fit between the pollinator body and the flower (Neff and Simpson 1981; Steiner and Whitehead 1991; Nattero et al. 2010; Cosacov et al. 2013; Murúa and Espíndola 2015; Hollens et al. 2017; Maubecin 2019). However, at a geographic scale, pollinator's phenotype can be strongly influenced by the physical environment. In this way, latitude and altitude have been reported as important abiotic factors acting on pollinator size (Daly et al. 1991; Malo and Baonza 2002). While most studies of oil bees have focused on the particular covariation between pollinator and floral traits, little is known about the influence of abiotic factor on phenotypic variation of oil bees.

Under this scenario, it would be interesting to study the specialisation in pollen collection and the phenotypic variation in morphological traits of oilcollecting bees across their distribution range. This kind of studies improves our understanding of ecological and evolutionary processes that occur at a geographic scale (Herrera et al. 2006; Ferreiro et al. 2015). Chalepogenus Holmberg is an oilcollecting bee genus (Apidae: Tapinotaspidini) functionally specialised in collecting this particular floral reward by means of special collecting structures of the fore basitarsus (Cocucci et al. 2000). As far as we know, Chalepogenus bees pollinate oilflowers of species belonging to the families Calceolariaceae, Iridaceae and Solanaceae from South America (Cocucci 1991; Rasmussen and Olesen 2000; Cocucci and Vogel 2001). A previous revision of the genus recognised a total of 21 species (Roig Alsina 1999), but little is known about pollination interactions and pollen preferences of most of them. Chalepogenus cocuccii Roig Alsina, in particular, is a species characterised by black cuticle contrasting with orange antennae, included in the nigripes group (Roig Alsina 1999). It is an endemic species of Argentina that has been previously recorded visiting flowers of the Solanaceae species Nierembergia browallioides and $N$. linariifolia var. linariifolia (Cocucci 1991), and in a single record of Senecio sp. (Asteraceae; Roig Alsina 1999). These previous observations suggest that $C$. cocuccii is likely to be a Nierembergia specialist, but until now there was not enough information to confirm this suggestion. Several species of Nierembergia occur across the distribution range of $C$. cocuccii (Hunziker et al. 1995), but the floral visitors of only some of them have been reported (Cocucci 1991). Nierembergia flowers are characterised by a salverform corolla with a long floral tube that does not contain nectar. The fertile parts of the flower 
emerge from the centre of the corolla limb (Cocucci 1991, Cocucci and Hunziker 1995), and the fatty oil is produced in an oil gland or elaiophore that consist in a cover of brief trichomes located in the upper surface of the corolla limb, near the base of the stamen filaments (Cocucci 1991), so that both rewards, oil and pollen, are exposed and accessible to bees. It has been reported that Chalepogenus bees can harvest both rewards in Nierembergia flowers during the same visit, exhibiting different behaviours while gathering oil or pollen (Cocucci 1991).

By making observations, collecting bee individuals in the field across the whole geographic range, and adding specimens obtained from previous collections, we performed a study on pollen collection, pollination interactions and phenotypic variation of the endemic and quite rare oil-collecting bee Chalepogenus cocuccii in order to answer the following questions: (1) does the specialization in oil collection of $C$. cocuccii involve specialisation in pollen collection?, (2) can we consider C. cocuccii a bee species specialised in the collection of rewards on Nierembergia flowers across its distribution range? and finally (3) does $C$. cocuccii vary phenotypically across its geographic range in relation to abiotic factors?

\section{MATERIAL AND METHODS}

\subsection{Sampling and field observations}

All field study sites were located in north-west Argentina, covering the whole distribution range of $C$. cocuccii. The study was carried out in the following locations: Tafi del Valle (TV: S $26^{\circ} 46^{\prime}$ $38^{\prime \prime}, \mathrm{W} 65^{\circ} 43^{\prime} 45^{\prime \prime}, 2787 \mathrm{~m}$ of altitude) and El Infiernillo (INF: S $26^{\circ} 44^{\prime} 14^{\prime \prime}, \mathrm{W} 65^{\circ} 47^{\prime} 28^{\prime \prime}$, $3038 \mathrm{~m}$ of altitude) in Tucumán province; Azul Pampa (AZP: S $22^{\circ}$ 58' 7", W 65²6' 19', 3530 m of altitude) in Jujuy province; and Cuesta Capillitas ( 2 sites, CAP1: S $27^{\circ} 28^{\prime} 15^{\prime \prime}$, W $66^{\circ}$ $23^{\prime} 39^{\prime \prime}, 2224 \mathrm{~m}$ of altitude and CAP2: S $27^{\circ} 22^{\prime}$ $45^{\prime \prime}, \mathrm{W} 66^{\circ} 22^{\prime} 23^{\prime \prime}, 3121 \mathrm{~m}$ of altitude) and Las Chacritas (CH: S $27^{\circ} 41^{\prime} 25^{\prime \prime}, \mathrm{W} 65^{\circ} 55^{\prime} 20^{\prime \prime}$, $1821 \mathrm{~m}$ of altitude) in Catamarca province (Figure 1). Observations and the capture of bee individuals on Nierembergia flowers were performed in all studied locations. Observations were performed during the short flowering time of Nierembergia species in the studied area, in January and February of 2015 and 2016. Only one Nierembergia population was present at each location where at least 10 different flower patches were observed during 15 to $20 \mathrm{~min}$ time periods recording number of visits and identity of the visitors. At each location between one to five individuals of $C$. cocuccii were captured, and their identity was confirmed using the dichotomous key for Chalepogenus species (Roig Alsina 1999) and individuals from previous collections as reference. Most bees were females, captured during flower visits. Due to weather conditions, observation time varied at each site; since pollinators' activity was strongly affected by cold and cloudy weather, we visited some sites several times, totalising $79 \mathrm{~h}$ of observations and 30 captured specimens ( 25 females and 5 males).

\subsection{Pollen loads analyses}

We analysed 17 pollen loads, 12 of them obtained from 12 females of $C$. cocuccii collected in the field, and five obtained from five female specimens deposited in collections (Museo Argentino de Ciencias Naturales "Bernardino Rivadavia", Buenos Aires, Argentina, and Laboratorio de Ecología Evolutiva y Biología Floral, Instituto Multidisciplinario de Biología Vegetal, Córdoba, Argentina), covering the whole range of the bee (Table SI). Pollen loads were removed carefully from tibial scopal hairs with insect pins (see Westrich and Schmidt 1986). Only scopal pollen was sampled to avoid contamination from grains passively attached onto the bee body during oil gathering. Pollen grains were picked up with a small piece of glycerin jelly embedded in fuchsin staining to increase contrast, mounted on slides, liquefied by heating and spread over using a thin glass (Beattie 1971). Samples were analysed under a light microscope (Zeiss Axiophot). Pollen grains were photographed with an Olympus DP71 camera and compared with reference samples performed with pollen from those plant species where bees were captured (as performed in Larkin et al. 2008). Pollen grains different from 

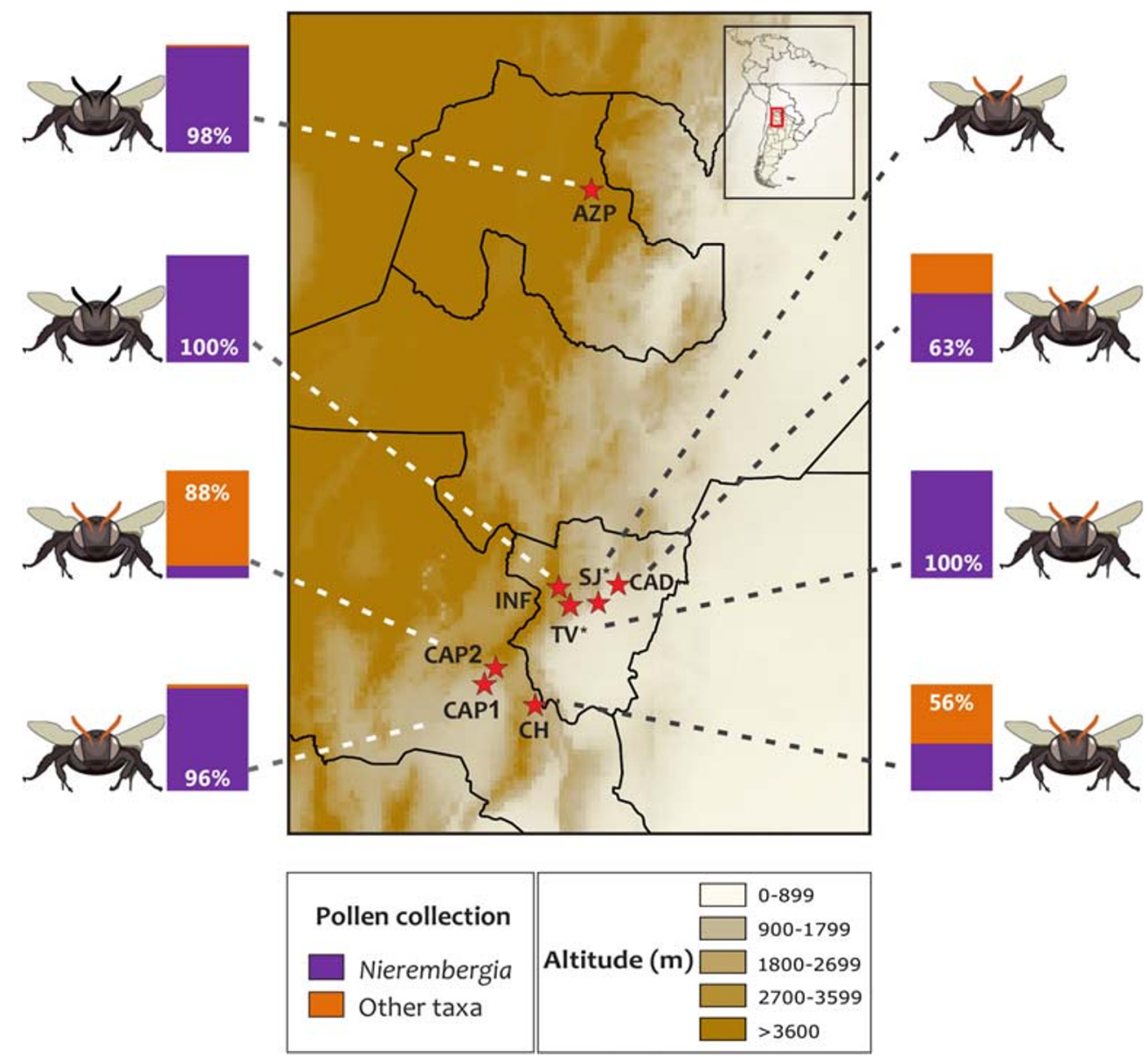

Figure 1. Geographic distribution of sampling sites and percentage of pollen types in pollen loads, and coloration morphotypes of $C$. cocuccii at each site. Inset depicts a relief map of South America, with the study area indicated by a box. The map includes a colour gradation according to the altitude of the area. Bars indicate the relative proportion of pollen from Nierembergia and other taxa at each site. Each studied site is indicated by a star which is accompanied by a drawing of the corresponding C. cocuccii morphotype. Asterisks indicate sites studied from specimens deposited in collections (MACN and IMBIV). Site abbreviations, see Table SI.

Nierembergia were identified according to the literature (Erdtman 1966; Markgraf and D'Antoni 1978; Pire et al. 1998, 2001, 2006). Unidentified pollen types were only identified at higher taxonomic levels. The amount of pollen types in each sample was estimated in percentages based on a count of 1000 grains per sample, when possible; those species accounting for less than $1 \%$ of pollen grains were considered as possible contamination and excluded from the analyses (Westrich and Schmidt 1986). The absolute amount of pollen loads was not considered. Several parameters were calculated per site: percentage of individuals carrying pollen of each plant species, absolute minimum and maximum number of pollen grains of each plant species and mean percentage and standard error of pollen grains.

To categorise $C$. cocuccii in terms of diet specialisation, we followed the criterion adopted by Larkin et al. (2008), which considers the quantity of pollen sources and categorises a bee species as narrowly oligolectic when at least $90 \%$ of the total pollen corresponded to pollen grains of a single host type, and broadly oligolectic otherwise. 


\subsection{Phenotypic variation of bees and the influence of abiotic factors}

In order to explore phenotypic variation of bees, the 30 collected $C$. cocuccii individuals together with seven specimens obtained from previous collections (Museo Argentino de Ciencias Naturales "Bernardino Rivadavia", Buenos Aires, Argentina, and Laboratorio de Ecología Evolutiva y Biología Floral, Instituto Multidisciplinario de Biología Vegetal, Córdoba, Argentina) were photographed under a stereomicroscope Leica M420 at a dorsal, side and ventral view, totalising 32 female and 5 male individuals (Table SI). Then, general body and leg measurements were obtained from the digital photographs using SigmaScan ${ }^{\circledR}$ (Systat Software, USA) software. Phenotypic measurements included: total body length (LENGTH), maximum body width (WIDTH), and height of the bee (HEIGHT), total length of the forelegs (FORELEG LENGTH), and forebasitarsal length (BASITARSAL LENGTH) (Figure 2).

A principal component analysis (PCA) was performed with the phenotypic measurements to observe phenotypic variation among individuals from different sites. In order to evaluate any association between the bee phenotypic traits and geographic abiotic variation, we first explored the variation in abiotic conditions among sites by performing a PCA with abiotic variables and a PCA only with selected climatic variables. Then, we performed a redundancy analysis (RDA) to evaluate in a general way to what extent the characteristics of the sites (geographic position, altitude and climatic variables) explained the phenotypic variation among bees. For these analyses, the abiotic variables included the geographic position (latitude - LAT and longitude - LONG), altitude (ALT) and climatic variables of the eight collection sites. For the museum specimens with no GPS data available, we obtained the georeferences from Google Earth (https://www. google.com/earth/download/ge/) according to the locality specified in the Museum database. We extracted climatic data of all the sites by downloading 19 variables obtained from a global set of satellite-based bioclimatic variables (MERRAclim; Vega et al. 2017) from Dryad Digital Repository (2000s decade; 2.5 arcmin resolution, http://datadryad.org/resource/doi:10.5061 /dryad.s2v81). To ensure statistical independence, we performed a correlation analysis between climatic variables to select only those that were not highly correlated $(r<0.8)$. Annual mean temperature (T_MEAN), mean diurnal temperature range ( $\bar{T} \_$D_RANGE), isothermality (ISOTHER), maximum temperature of warmest month ( $T_{-}$MAX), minimum temperature of coldest month (T_MIN), temperature annual range (T_A_RANGE), annual mean specific humidity (PP_ANNUAL), specific humidity of the wettest month (PP_WET) and specific humidity of the driest month (PP_DRY) were the nine climatic variables selected after the correlation analysis.
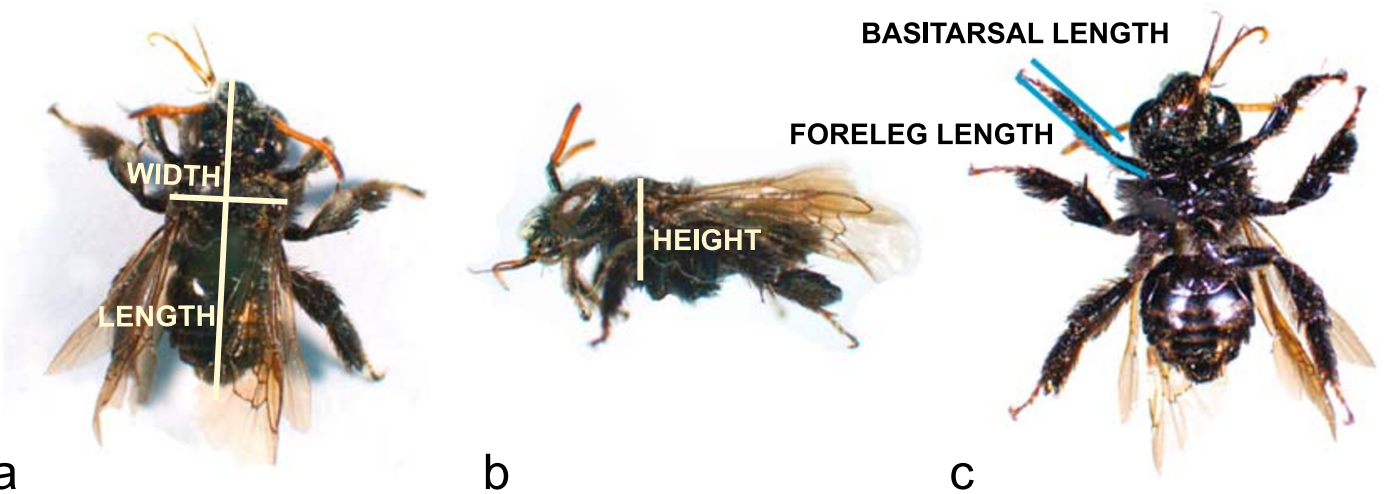

Figure 2. Linear morphometric measurements on bees. a Dorsal view showing body length (LENGTH) and body width (WIDTH). b Lateral view showing body height (HEIGHT). c Ventral view showing the total length of the forelegs (FORELEG LENGTH) and forebasitarsal length (BASITARSAL LENGTH). 
Additionally, given that two coloration morphotypes not previously reported in the literature were found among $C$. cocuccii individuals (see "Sect. 3"), we performed ANOVA and PCA to assess and observe potential differences in the phenotypic traits considered between these unexpected coloration morphotypes. Shapiro and Barlett test were previously applied to confirm data normality and statistical homogeneity.

\section{RESULTS}

\subsection{Geographic variation of pollination interactions and reward foraging behaviour}

In all sampled sites, we found $C$. cocuccii bees visiting flowers of Nierembergia, the focal plant genus, and the Nierembergia host species varied across the geographic range of the bee. Field observations revealed that females of this bee species collected both pollen and oil from the same visited Nierembergia flower. Observations also revealed that $C$. cocuccii bees made contact with the fertile parts of Nierembergia flowers while collecting oil or pollen, thus pollinating all the Nierembergia species present in the study sites, some of which were not previously recorded as oil hosts of this bee species. C. cocuccii visited flowers of $N$. linariifolia var. linariifolia, N. pulchella (both varieties, pulchella and macrocalyx), N. browallioides, $N$. veitchii and $N$. tucumanensis. It is also important to mention that it was the only pollinator observed on flowers of $N$. pulchella var. macrocalyx and $N$. browallioiodes in the studied locations, while in the sites of the remaining Nierembergia species, there were also other oil bee species visiting the flowers.

The harvesting behaviour of females on flowers of Nierembergia matched the description made by Cocucci (1991) in N. browallioides . Oil and pollen harvesting behaviours were different, but consistent in all Nierembergia species (Figure 3), with the exception of $N$. tucumanensis, where the bee entered inside the bell-shaped corolla to collect oil and pollen from the lower anthers, climbing afterwards the column to gather pollen from the upper anthers. In general, females visited several flowers of a patch, although they did not always collect rewards. They carried out their task in a silent but very agile and fast flight, which generated certain difficulties when capturing them. Males were observed sleeping in the flowers in the early morning, and then patrolling flowers while females were collecting the rewards, as has already been reported for other solitary oil-bee species (Alves-dos-Santos et al. 2009; Pinheiro et al. 2017).
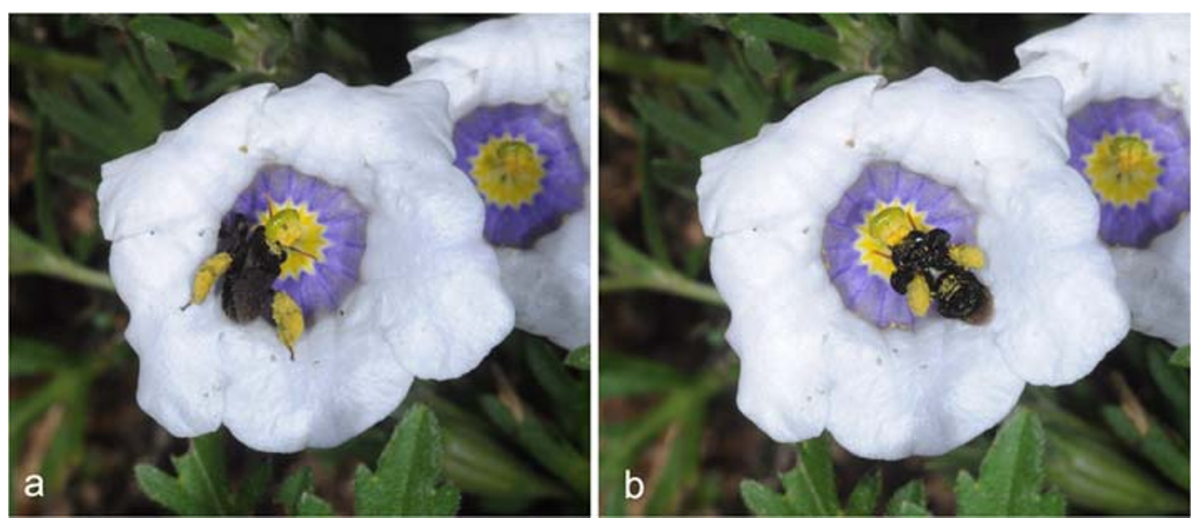

Figure 3. Harvesting behaviour of C. cocuccii females on flowers of Nierembergia pulchella. a Oil collection. Bees harvest oil with their forelegs while moving around the secretory corolla surface, touching the floral fertile parts with the front of the head. b Pollen collection. Bees climb the staminal column, seizing the filaments with their mandibles, and harvest pollen with their forelegs, transferring it immediately to the scopae. The bees touch the floral fertile parts while rolling over the column (Cocucci 1991). 


\subsection{Pollen load analyses}

Pollen load analyses showed that $C$. cocuccii bees visited a total of 22 different flowering plant species across its distribution range; however, Nierembergia pollen in general represented more than $90 \%$ of the total, so it was dominant in almost all samples. The total number of species within a sample (species richness) ranged from one to four in the analysed pollen loads. Thirteen of the 17 analysed pollen loads were practically pure samples of Nierembergia pollen; only four samples had low representation of Nierembergia pollen (Table I, Figure 1). We found an average of $499.88 \pm 105.36$ pollen grains of Nierembergia species and an average of $46.00 \pm 24.58$ pollen grains of other species per sample. Pollen grains of the remaining taxa included pollen types of Asteraceae, Malvaceae, Calceolaria, among others (Table I).

Table I. Summary of pollen analyses per site. For each plant species found in pollen loads, several parameters are provided: \% Ind, percentage of individuals carrying pollen of the corresponding plant species; Pollen min/max, minimum and maximum number of pollen grains; Mean $(\%) \pm S E$, mean and standard error of percentage of pollen grains. $n$, number of pollen samples, is provided for each site. Plant species name, when possible, is indicated. Asterisks indicate sites studied from specimens deposited in collections (MACN and IMBIV). Site abbreviations, see Table SI

\begin{tabular}{|c|c|c|c|c|}
\hline Site & Plant species & $\%$ Ind & Pollen $\min / \max$ & Mean $(\%) \pm \mathrm{SE}$ \\
\hline \multirow[t]{3}{*}{$\mathrm{AZP}(n=6)$} & Nierembergia pulchella var. macrocalyx & 100.0 & $10-988$ & $98.0 \pm 1.1$ \\
\hline & Asteraceae 1 & 16.7 & $0-68$ & $1.1 \pm 1.3$ \\
\hline & Eudicotyledoneae 1 & 50.0 & $0-20$ & $0.9 \pm 0.4$ \\
\hline \multirow[t]{6}{*}{ CAP2 $(n=2)$} & Nierembergia pulchella var. pulchella & 100.0 & $3-5$ & $11.8 \pm 1.4$ \\
\hline & Asteraceae 2 & 50.0 & $0-22$ & $37.9 \pm 37.9$ \\
\hline & Calceolaria sp. & 50.0 & $0-27$ & $35.5 \pm 35.5$ \\
\hline & Eudicotyledoneae 2 & 50.0 & $0-4$ & $5.3 \pm 5.2$ \\
\hline & Eudicotyledoneae 3 & 50.0 & $0-4$ & $6.9 \pm 6.9$ \\
\hline & Ipomea type & 50.0 & $0-2$ & $2.6 \pm 2.6$ \\
\hline $\operatorname{INF}(n=1)$ & Nierembergia tucumanensis & 100.0 & 148 & 100.0 \\
\hline \multirow[t]{3}{*}{ CAP1 $(n=2)$} & Nierembergia linariifolia var. linariifolia & 100.0 & $310-507$ & $96.1 \pm 3.9$ \\
\hline & Solanum type 1 & 50.0 & $0-34$ & $3.1 \pm 3.1$ \\
\hline & Eudicotyledoneae 4 & 50.0 & $0-9$ & $0.8 \pm 0.8$ \\
\hline \multirow[t]{4}{*}{$\mathrm{CH}(n=1)$} & Nierembergia veitchii & 100.0 & 4 & 44.4 \\
\hline & Geranium sp. & 100.0 & 2 & 22.2 \\
\hline & Oxalis sp. 1 & 100.0 & 2 & 22.2 \\
\hline & Eudicotyledoneae 5 & 100.0 & 1 & 11.1 \\
\hline $\mathrm{TV}^{*}(n=2)$ & Nierembergia browalloides & 100.0 & $6-987$ & 100.0 \\
\hline \multirow[t]{7}{*}{$\mathrm{CAD}^{*}(n=3)$} & Nierembergia browalloides & 66.7 & $0-939$ & $62.3 \pm 25.4$ \\
\hline & Nierembergia linariifolia & 33.3 & $0-6$ & $0.4 \pm 0.4$ \\
\hline & Eudicotyledoneae 6 & 33.3 & $0-396$ & $27.5 \pm 22.4$ \\
\hline & Solanum type 2 & 66.7 & $0-61$ & $4.0 \pm 1.8$ \\
\hline & Eudicotyledoneae 7 & 33.3 & $0-23$ & $1.6 \pm 1.3$ \\
\hline & Abutilon type & 33.3 & $0-22$ & $1.5 \pm 1.3$ \\
\hline & Oxalis sp. 2 & 33.3 & $0-9$ & $0.4 \pm 0.3$ \\
\hline
\end{tabular}




\subsection{Phenotypic variation of bees and the} influence of abiotic factors

The first two principal components of the PCA explained $88 \%$ of the total variation recorded among individuals of $C$. cocuccii. Phenotypic variation was mainly related to body length and foreleg length, the variables that most contributed to maximum variation of $\mathrm{PC} 1$ and $\mathrm{PC} 2$ axes, respectively, and observations per site overlapped (Figure 4a). Minimum, maximum and mean values of the measured phenotypic traits were summarised in Table II and complete data set is provided in Table SII.

a

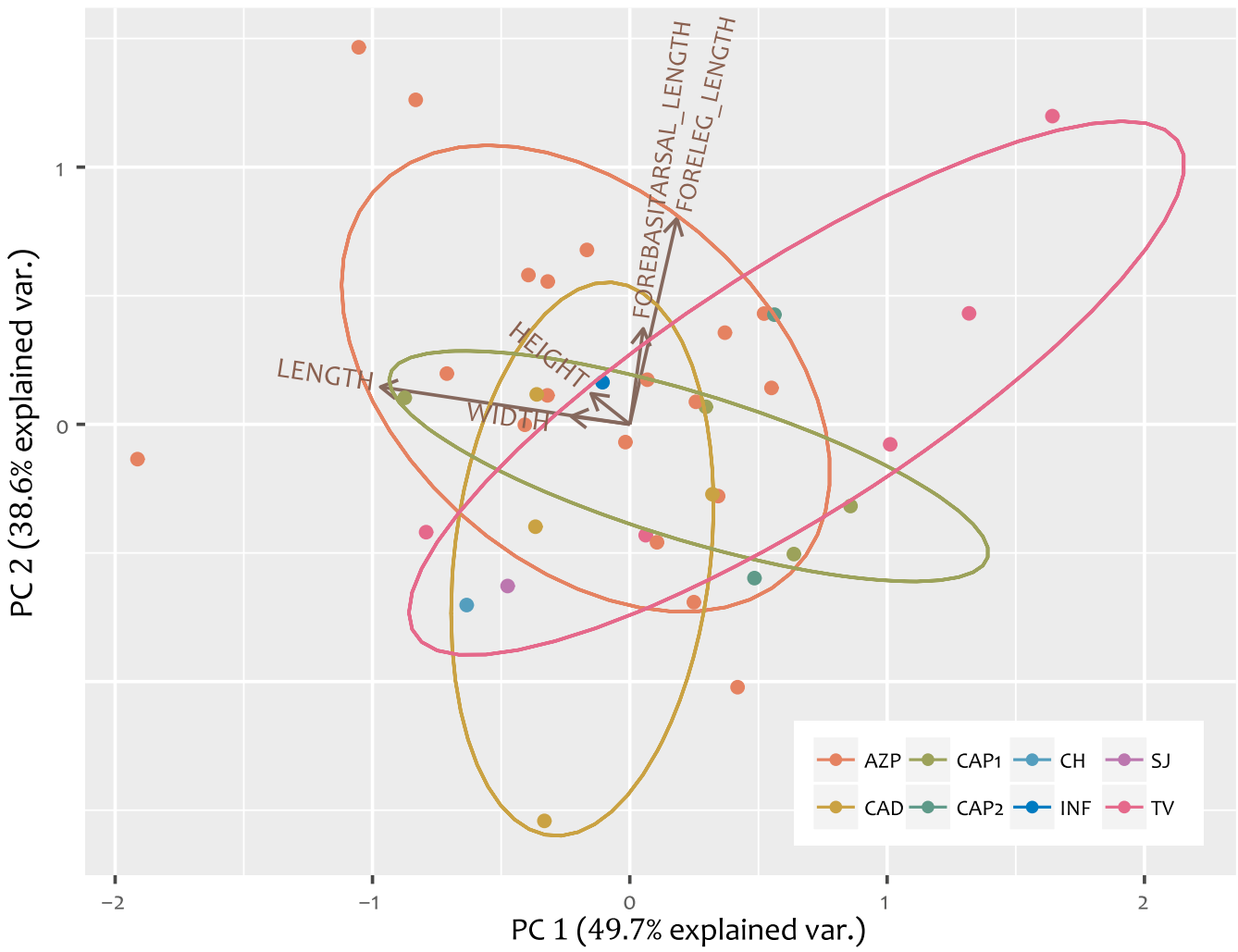

b

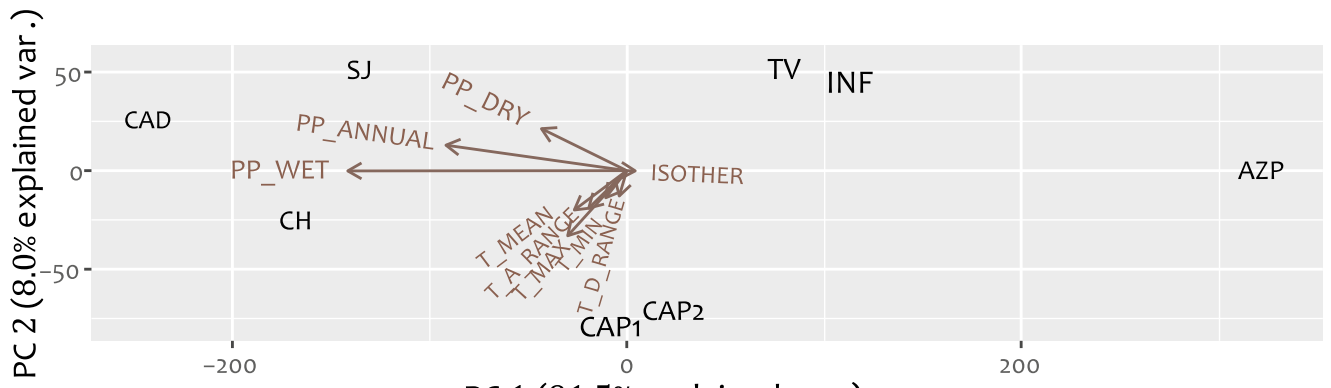

PC 1 (91.5\% explained var.)

Figure 4. a Biplot of the first two axes of the PCA ordination for individuals of $C$. cocuccii performed with morphometric data. Each observation is coloured in correspondence to collection sites. b Biplot of the first two axes of the PCA ordination performed only with climatic variables for the set of sites where C. cocuccii was collected. The amount of variance explained by each axis is provided in parentheses. For site and climatic variables abbreviations, see Table SI and "Sect. 2", respectively. 
Table II. Minimum (Min), mean (Mean) and maximum (Max) values of the measured body and legs' parts of C. cocuccii individuals

\begin{tabular}{llll}
\hline & Min $(\mathrm{mm})$ & Mean $(\mathrm{mm})$ & Max $(\mathrm{mm})$ \\
\hline Body length & 6.03 & 7.27 & 9.11 \\
Body width & 2.14 & 2.72 & 3.27 \\
Body height & 2.05 & 2.44 & 3.07 \\
$\begin{array}{l}\text { Foreleg length } \\
\text { Forebasitarsal }\end{array}$ & 2.69 & 4.18 & 5.65 \\
$\quad$ length & 1.28 & 1.84 & 2.49 \\
\hline
\end{tabular}

The PCA performed with the spatial data and the selected climatic variables of the eight sites showed that the variation among sites was mainly related to site altitude, being AZP, INF, CAP2 and $\mathrm{TV}$, the highest sites (results not shown). In the PCA performed using the selected climatic variables of each of the eight sites, the first axis accounted for most of the total variation $(91.5 \%)$ across populations, showing that sites TV, INF and AZP are characterised by a more humid climate than CAD, CH and SJ (Figure 4b). Despite variation among sites, RDA revealed that geographic and climatic variables did not explain phenotypic variation among bee individuals of C. cocuccii $(p=0.737)$.

One of the key characters to recognise C. cocuccii species is the orange colour of the antennae present in both, female and male individuals. However, we found colour variation in the antennae among some $C$. cocucci individuals. All individuals collected in two of the studied locations (AZP and INF) showed completely dark antennae, in contrast to the orange-red antennae of the bees of the remaining sites (Figures 1 and 5). The males genitalia, another key character to distinguish species of Chalepogenus, did not differ between individuals with dark and orange antennae. This phenotypic variation in antennae colour has not been reported before, and thus, not included previously in the dichotomous key for species identification (Roig Alsina 1999). ANOVA between these two morphotypes showed significant differences in body width and body height between individuals with dark and orange antennae (Table III); however, these differences were small (mean width $=2.84 \mathrm{~mm}$ and mean height $=$
$2.57 \mathrm{~mm}$ for dark antennae individuals, and mean width $=2.59 \mathrm{~mm}$ and mean height $=2.30 \mathrm{~mm}$ for orange antennae individuals). PCA results showed that there is no phenotypic differentiation between morphotypes (Fig. 6).

\section{DISCUSSION}

The results of the present study provide valuable information about the unexplored ecology of the oil-collecting bee Chalepogenus cocucci, in respect to pollen collection, pollination interactions, rewards gathering behaviour and phenotypic variation. From this work, we answered three main questions:

Does the specialisation in oil collection of C. cocuccii involve specialisation in pollen collection? Our results showed that $C$. cocuccii is a specialised bee species, both in oil and pollen collection. According to its preferences in pollen collection, C. cocuccii is narrowly oligolectic, based on visitation records and pollen loads composition. Narrow oligolecty refers to the bee specialisation in the same few species of pollen hosts (Cane and Sipes 2006), phylogenetically related host taxa within a genus, tribe or family, across the geographic range (Larkin et al. 2008). This species was observed collecting both rewards from the same floral resource in each site across the distribution range, all of which corresponded to the same plant genus. The observed specialisation was also confirmed by pollen loads analysis. According to Cane and Sipes (2006) and based on the present results, C. cocuccii may also be considered monolectic, i.e., bees that are restricted to a single floral host genus, rather than species.

Can C. cocuccii be considered a bee species specialised in the collection of rewards on Nierembergia flowers across its distribution range? Field observations of gathering behaviour and pollen analysis indicated that $C$. cocuccii had a preference for Nierembergia flowers, not only for oil but also for pollen collection, suggesting that this species is a Nierembergia specialist. Our results and previous data suggest that this bee species is phenotypically and ecologically specialised in Nierembergia (sensu 

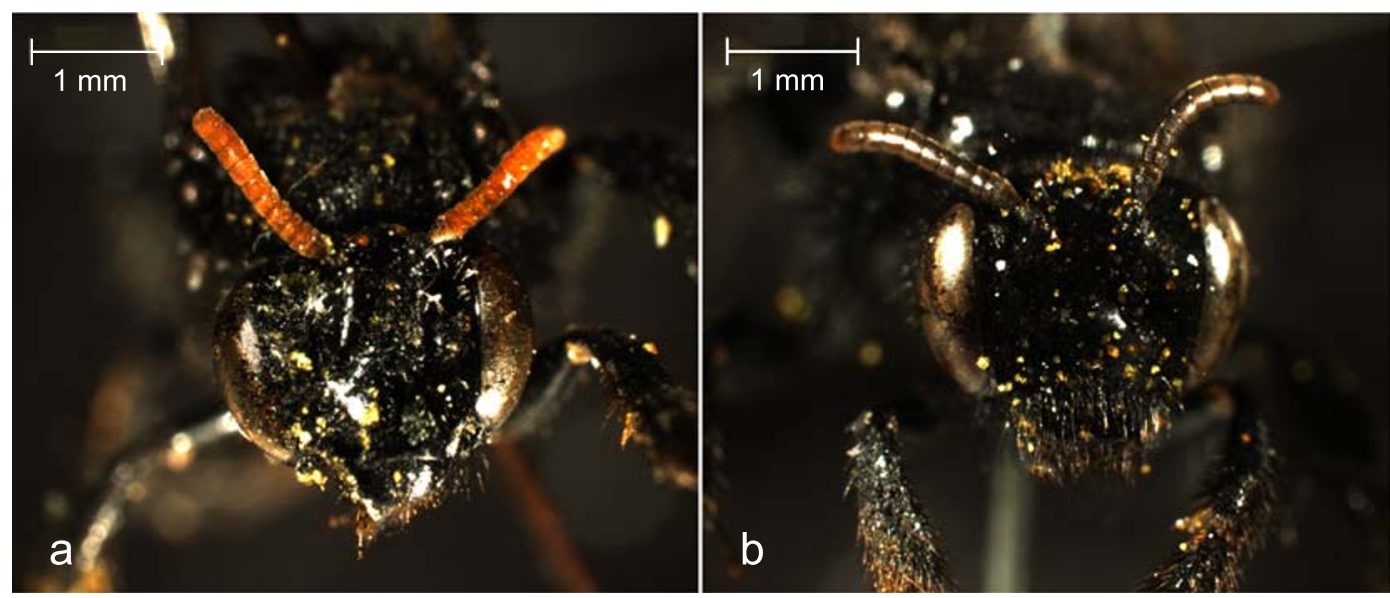

Figure 5. Frontal view of the head of $C$. cocuccii showing the difference in colour of the antennae. a Orange morphotype (collected in sites CAD, CAP1, CAP2, CH, SJ, TV). b Dark morphotype (collected in sites AZP and INF). For site abbreviations, see Table SI.

Armbruster 2017), since it shows specific adaptations for harvesting and transporting both floral rewards of Nierembergia (i.e., non-volatile oils and pollen), and it mainly interacts with species of this genus across its whole geographic range. In all the studied localities, females of $C$. cocuccii were observed actively collecting pollen from Nierembergia flowers until their scopas became full. Only in sites $\mathrm{CAP} 2$ and $\mathrm{CH}$, the females carried very few pollen grains, probably because they already unloaded the burden at their nests when captured. Thus, results obtained from these sites should be cautiously considered since they certainly do not reflect the real amount of pollen that females normally collect. Pollen of Calceolaria, another oil-flower genus,

Table III. ANOVA results. $F$ value and significance $p$ value are informed. Total number of individuals: 37 (17 with orange antennae and 20 with dark antennae).

\begin{tabular}{ll}
\hline & $F(p)$ \\
\hline Body length & $2.51(0.122)$ \\
Body width & $10.58(0.002)^{*}$ \\
Body height & $16.56(0.0002)^{*}$ \\
Foreleg total length & $2.26(0.141)$ \\
Forebasitarsus length & $1.22(0.277)$ \\
\hline
\end{tabular}

Statistical significance is indicated with an asterisk was found in only one site, although species of Calceolaria were frequent in most of the studied sites. Additionally it has never been reported observations of $C$. cocuccii visiting Calceolaria species (Sérsic 2004).

Within the genus Chalepogenus, it seems that the specificity in pollination interactions is variable (Roig Alsina 1999), but there is little information about rewards harvesting within genus Chalepogenus. Non-volatile oils are the main reward in flowers of Nierembergia, and many of its species are visited by Chalepogenus species which harvest this reward and also collect pollen from the flowers (Cocucci 1991; Maubecin 2019; unpubl. data). The present results suggest that, within the genus, C. cocuccii would be a specialised species. However, it remains unknown which are the causes of this putative specialisation on Nierembergia flowers. Practically, no studies of pollen loads of members of Tapinotaspidini tribe have been carried out, but it has been reported that Chalepogenus nigripes, a sister species of C. cocuccii (Roig Alsina 1999), also predominantly collect pollen of Nierembergia (Cocucci 1991). Thus, it would be interesting to perform a detailed study of the specialisation in pollen collection in these bee group to evaluate if it is a shared phenomenon among Chalepogenus species originated from common evolutionary histories. Most of the studied populations of $C$. cocuccii were found at high altitude 


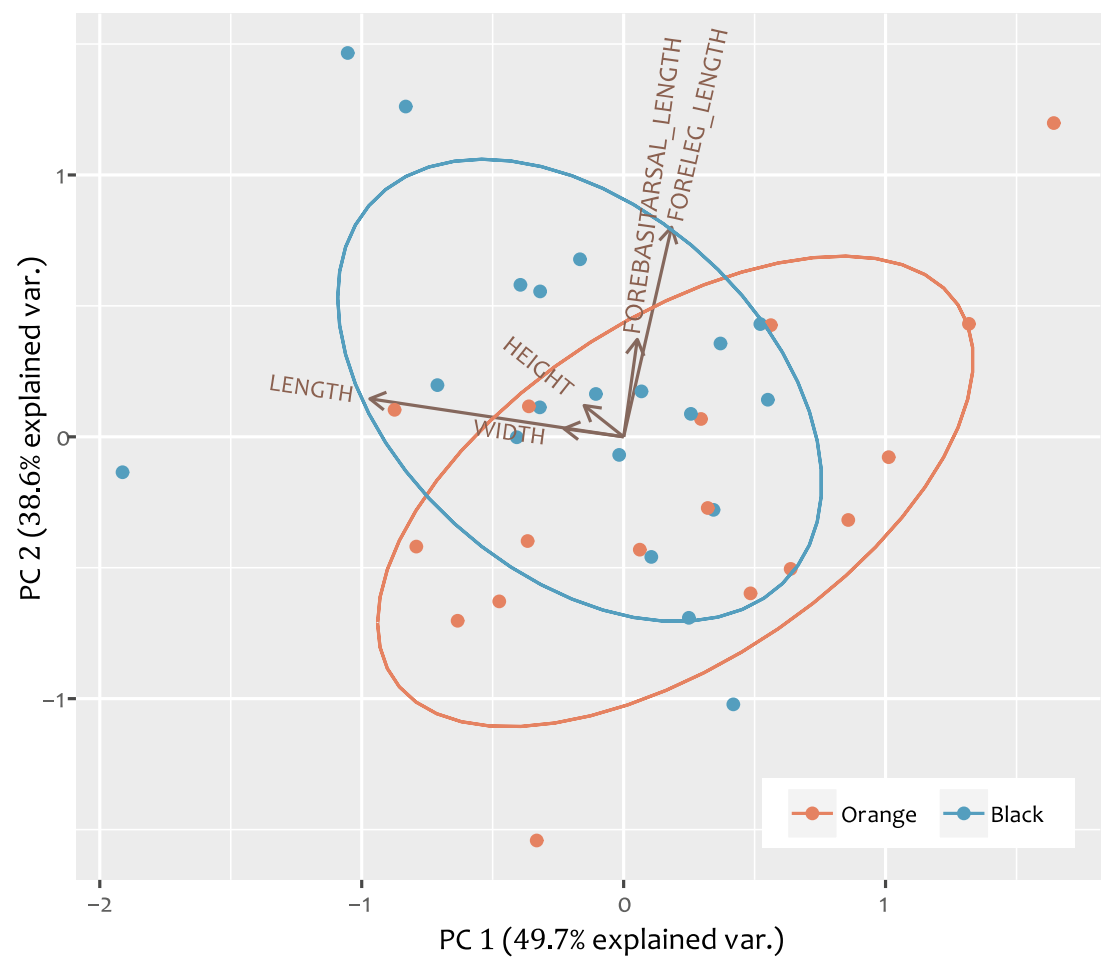

Figure 6. Biplot of the first two axes of the PCA ordination performed with morphometric measurements of individuals of $C$. cocuccii. Red dots correspond to individuals with orange antennae and blue dots to individuals with dark antennae. The amount of variance explained by each axis is provided in parentheses. For abbreviations of measured phenotypic traits, see "Sect. 2".

environments where pollination networks tend to have simple structures (Olesen and Jordano 2002), and the preservation of specific interactions becomes critical. C. cocuccii interacted with different Nierembergia species throughout its geographic range, in fact being the only recorded pollinator in $N$. pulchella var. macrocalyx and $N$. browallioiodes, suggesting that C. cocuccii may be a key pollinator for Nierembergia species within the distribution range of the bee species.

Does $C$. cocuccii vary phenotypically across its geographic range in relation to abiotic factors?Phenotypic analysis showed that the overall body size of this species remains fairly constant at a geographic level, with no apparent influence of abiotic factors, but two coloration morphotypes were found in the studied localities, a phenotypic variation not previously reported for this species. Although body size among C. cocuccii individuals was not related to geographic and climatic variables, individuals with dark antennae were found in two of the highest sites (INF and AZP sites). Many studies reported that insects are often darker at high altitudes, where temperature is low and ultraviolet radiation intense (Rapoport 1969; Guppy 1986; Hodkinson 2005; Trullas et al. 2007; Mani 2013). The presence of two morphotypes within $C$. cocuccii could be related to this kind of adaptation, but more samplings at high altitude are needed to confirm this hypothesis. It would be also interesting to find out if there is an incipient species divergence process among populations. Likewise, information about levels of outcrossing between populations would also be valuable. Lastly, a molecular phylogeny is required to clarify the relationships between bee species and to corroborate the existing classification based on morphological characters. 


\section{ACKNOWLEDGEMENTS}

We thank María Elena García, Lilian Pasarelli and Melisa G. Geisa for pollen identification assistance; Andrea A. Cocucci for providing collection specimens and assistance in the field; Arturo Roig Alsina for the confirmation of the bee species identity and for providing collection specimens; Andrea Cosacov for valuable suggestions on the preliminary version and María Laura Guzman Rodriguez for revising the English version of the manuscript. CCM, LB and ANS acknowledge the Consejo Nacional de Investigaciones Científicas y Técnicas (CONICET) as postdoctoral and doctoral fellowship holders and researcher, respectively.

\section{AUTHOR CONTRIBUTIONS}

CCM and ANS designed the study, performed field sampling; LB performed pollen analyses; CCM performed morphometric measurements and data analysis; CCM, LB and ANS discused results and wrote the paper.

\section{FUNDING INFORMATION}

This work was supported by funds of the National Research Council of Argentina (CONICET, PIP 201101-00245, PIP 11220150100690CO) and the National Ministry of Science and Technology (FONCYT-PICT-2011-0837, PICT 2015-3089) to A.N.S.

\section{COMPLIANCE WITH ETHICAL STANDARDS}

Conflict of interest The authors declare that they have no conflict of interest.

Spécialisation dans la collecte de pollen, interactions de pollinisation et variation phénotypique de l'abeille collectrice d'huile Chalepogenus cocuccii.

abeilles collectrices d'huile / oligolectie / spécialisation / interactions de pollinisation / variation phénotypique.

Spezialisierung der Öl sammelnden Biene Chalepogenus cocuccii beim Pollensammeln, bei Bestäubungsinteraktionen und bei phänotypischen Variationen.
Öl sammelnde Bienen / Oligolektie / Spezialisierung / Bestäubungsinteraktionen / phänotypische Variationen

\section{REFERENCES}

Aguiar C.M.L. (2003) Flower visits of Centris bees (Hymenoptera: Apidae) in an area of caatinga (Bahia, Brazil). Stud. Neotrop. Fauna E. 38(1), 41-45

Alves-dos-Santos I., Machado I.C., Gaglianone M.C. (2007) História natural das abelhas coletoras de óleo. Oecol. Brasil. 11 (4), 544-557

Alves-dos-Santos I., Gaglianone M.C., Naxara S.R.C., Engel M.S. (2009) Male sleeping aggregations of solitary oil-collecting bees in Brazil (Centridini, Tapinotaspidini, and Tetrapediini; Hymenoptera: Apidae). Genet. Mol. Res. 8(2), 515-524

Armbruster W.S. (2017) The specialization continuum in pollination systems: diversity of concepts and implications for ecology, evolution and conservation. Funct. Ecol. 31 (1), 88-100

Beattie A.J. (1971) A technique for the study of insectborne pollen. Pan-Pac. Entomol. 47 (1), 82

Buchmann S.L. (1987) The ecology of oil flowers and their bees. Annu. Rev. Ecol. Syst. 18 (1), 343-369

Cane J.H., Sipes S. (2006) Characterizing floral specialization by bees: analytical methods and a revised lexicon for oligolecty. In Waser N.M., Ollerton J. (Eds.), Plantpollinator interactions: from specialization to generalization (pp. 99-122). The University of Chicago press, Chicago and London

Cane J.H., Eickwort G.C., Wesley F.R., Spielholz J. (1983) Foraging, grooming and mate-seeking behaviors of Macropis nuda (Hymenoptera, Melittidae) and use of Lysimachia ciliata (Primulaceae) oils in larval provisions and cell linings. Am. Midl. Nat. 110 (2), 257-264

Carneiro L.T., Aguiar A.J.C., Martins C.F., Machado I.C., Alves-dos-Santos I. (2015) Krameria tomentosa oil flowers and their pollinators: bees specialized on trichome elaiophores exploit its epithelial oil glands. Flora 215, 1-8

Cocucci A.A. (1991) Pollination biology of Nierembergia (Solanaceae). Plant Syst. Evol. 174 (1-2), 17-35

Cocucci A.A., Hunziker A.T. (1995) Estudios sobre Solanaceae. XLI. Nierembergia linariaefolia y $N$. pulchella: sus sinónimos y variedades. Darwiniana 33, 35-42

Cocucci A.A., Vogel S. (2001) Oil-producing flowers of Sisyrinchium species (Iridaceae) and their pollinators in southern South America. Flora 196 (1), 26-46

Cocucci A.A., Sérsic A., Roig Alsina A. (2000) Oilcollecting structures in Tapinotaspidini: their diversity, function and probable origin. Mitt. Münch. Entomol. Ges. 90, 51-74 
Cosacov A., Nattero J., Cocucci A.A. (2008) Variation of pollinator assemblages and pollen limitation in a locally specialized system: the oilproducing Nierembergia linariifolia (Solanaceae). Ann. Bot. 102 (5), 723-734

Cosacov A., Cocucci A.A., Sérsic A.N. (2013) Geographical differentiation in floral traits across the distribution range of the Patagonian oil-secreting Calceolaria polyrhiza: do pollinators matter? Ann. Bot. 113(2), 251-266

Cunha R., Blochtein B. (2003) Bionomia de Monoeca xanthopyga Harter-Marques, Cunha \& Moure (Hymenoptera, Apidae, tapinotaspidini) no Planalto das Araucárias, Rio Grande do sul. Brasil. Rev. Bras. Zool. 20 (1), 107-113

Daly H.V., Hoelmer K., Gambino P. (1991) Clinal geographic variation in feral honey bees in California, USA. Apidologie 22 (6), 591-609

Erdtman G. (1966) Pollen morphology and plant taxonomy. Angiosperm: an introduction to palynology I. Hafner Publishing Company, New York

Espíndola A., Pliscoff P. (2019) The relationship between pollinator visits and climatic suitabilities in specialized pollination interactions. Ann. Entomol. Soc. Am. 112, 150-157. https://doi.org/10.1093/aesa/say042

Ferreiro G., Baranzelli M.C., Sérsic A.N., Cocucci A.A. (2015) Clinal variability of oil and nectar rewards in Monttea aphylla (Plantaginaceae): relationships with pollinators and climatic factors in the Monte Desert. Bot. J. Linn. Soc. 178 (2), 314-328

Ferreiro G., Baranzelli M.C., Sersic A.N., Cocucci A.A. (2017) Patterns of phenotypic selection for oil and nectar in Monttea aphylla (Plantaginaceae) in a geographic mosaic of interactions with pollinators. Flora 232, 47-55

Gaglianone M.C. (2005) Nesting biology, seasonality, and flower hosts of Epicharis nigrita (Friese, 1900) (Hymenoptera: Apidae: Centridini), with a comparative analysis for the genus. Stud. Neotrop. Fauna E. 40 (3), 191-200

Giannini T.C., Pinto C.E., Acosta A.L., Taniguchi M., Saraiva A.M., Alves-dos-Santos I. (2013) Interactions at large spatial scale: the case of Centris bees and floral oil producing plants in South America. Ecol. Model. 258, 74-81

Guppy C.S. (1986) Geographic variation in wing melanism of the butterfly Parnassius phoebus F.(Lepidoptera: Papilionidae). Can. J. Zool. 64 (4), 956-962

Herrera C.M., Castellanos M.C., Medrano M. (2006) Geographical context of floral evolution: towards an improved research program in floral diversification. In Harder L.D., Barrett S.C.H. (Eds.), Ecology and evolution of flowers (pp. 278-294). Oxford University Press, Oxford

Hodkinson I.D. (2005) Terrestrial insects along elevation gradients: species and community responses to altitude. Biol. Rev. 80 (3), 489-513

Hollens H., van der Niet T., Cozien R., Kuhlmann M. (2017) A spur-ious inference: pollination is not more specialized in long-spurred than in spurless species in Diascia-Rediviva mutualisms. Flora 232, 73-82

Hunziker A.T., Cocucci A.A., Subils R. (1995) Subtribu VIIb. Nierembergiinae Hunz. et Cocucci. Flora Fanerogamica Argentina: Solanaceae. Proflora 15, 317

Larkin L.L., Neff J.L., Simpson B.B. (2008) The evolution of a pollen diet: host choice and diet breadth of Andrena bees (Hymenoptera: Andrenidae). Apidologie 39, 133-145

Malo J.E., Baonza J. (2002) Are there predictable clines in plant-pollinator interactions along altitudinal gradients? The example of Cytisus scoparius (L.) link in the sierra de Guadarrama (Central Spain). Divers. Distrib. 8(6), 365-371

Mani, M. S. (2013) Ecology and biogeography of high altitude insects (Vol. 4). Springer Science \& Business Media.

Markgraf V., D'Antoni H.L. (1978) Pollen Flora of Argentina. University of Arizona Press, Arizona

Maubecin, C. C. (2019) El rol de los polinizadores y la historia filogenética sobre la divergencia, integración y modularidad del fenotipo floral de Nierembergia (Solanaceae). PhD Thesis, Universidad Nacional de Córdoba, Argentina.

Murúa M., Espíndola A. (2015) Pollination syndromes in a specialised plant-pollinator interaction: does floral morphology predict pollinators in Calceolaria? Plant Biol. 17 (2), 551-557

Nattero J., Cocucci A.A., Medel R. (2010) Pollinatormediated selection in a specialized pollination system: matches and mismatches across populations. J. Evolution. Biol. 23 (9), 1957-1968

Neff J., Simpson B. (1981) Oil-Collecting Structures in the Anthophoridae (Hymenoptera): Morphology, Function, and Use in Systematics. J. Kansas Entomol. Soc. 54 (1), 95-123

Neff J.L., Simpson B.B. (2017) Vogel's great legacy: the oil flower and oil-collecting bee syndrome. Flora 232, 104-116

Olesen J.M., Jordano P. (2002) Geographic patterns in plant-pollinator mutualistic networks. Ecology 83 (9), 2416-2424

Pinheiro M., Alves-dos-Santos I., Sazima M. (2017) Flowers as sleeping places for male bees: somehow the males know which flowers their females prefer. Arthropod-Plant Inte. 11 (3), 329-337

Pire, S. M., Anzótegui, L. M., Cuadrado, G. A. (1998) Flora polínica del nordeste argentino (Vol. 1). EUDENE, UNNE, Corrientes.

Pire, S. M., Anzótegui, L. M., Cuadrado, G. A. (2001). Flora polínica del nordeste argentino (Vol). 2. EUDENE, UNNE, Corrientes.

Pire, S. M., Anzótegui, L. M., Cuadrado, G. A. (2006). Flora polínica del nordeste argentino (Vol). 3. EUDENE, UNNE, Corrientes. 
Possobom C.C.F., Machado S.R. (2017) Elaiophores: their taxonomic distribution, morphology and functions. Acta Bot. Bras. 31 (3), 503-524

Rapoport E.H. (1969) Gloger's rule and pigmentation of Collembola. Evolution 23, 622-626

Rasmussen C., Olesen J.M. (2000) Oil flowers and oilcollecting bees. Norske Vidensk. Akad. I. Mat. Nat. K1. Skrifter. Ny Serie 39, 23-31

Rego M.M.C., Albuquerque P.M.C., Ramos M.C., Carreira L.M. (2006) Aspectos da Biologia de Nidificação de Centris flavifrons (Friese) (Hymenoptera: Apidae, Centridini), um dos Principais Polinizadores do Murici (Byrsonima crassifolia 1. Kunth, Malpighiaceae), no Maranhão. Neotrop. Entomol. 35 (5), 579-587

Ribeiro E.K.M.D., Rêgo M.M.C., Machado I.C.S. (2008) Cargas polínicas de abelhas polinizadoras de Byrsonima chrysophylla Kunth.(Malpighiaceae): fidelidade e fontes alternativas de recursos florais. Acta Bot. Bras. 22 (1), 165-171

Roig Alsina A. (1999) Revisión de las abejas colectoras de aceites del género Chalepogenus Holmberg (Hymenoptera, Apidae, Tapinotaspidini). Rev. Mus. Argentino Cienc. Nat. 1, 67-101

Sérsic A.N. (2004) Reproductive biology of the genus Calceolaria . Stapfia 82, 1-121

Sérsic A.N., Cocucci A.A. (1999) An unusual kind of nectary in the oil flowers of Monttea: its structure and function. Flora 194 (4), 393-404
Simpson B.B., Neff J.L. (1981) Floral rewards: alternatives to pollen and nectar. Ann. Mo. Bot. Gard. 68, 301-322

Steiner K.E., Whitehead V.B. (1991) Oil flowers and oil bees: further evidence for pollinator adaptation. Evolution 45(6), 1493-1501

Trullas S.C., van Wyk J.H., Spotila J.R. (2007) Thermal melanism in ectotherms. J. Therm. Biol. 32 (5), 235245

Vega G.C., Pertierra L.R., Olalla-Tárraga M.Á. (2017) MERRAclim, a high-resolution global dataset of remotely sensed bioclimatic variables for ecological modelling. Scientific data 4, 170078

Vinson S.B., Frankie G.W. (1988) A comparative study of the ground nests of Centris flavifrons and Centris aethiocesta (Hymenoptera: Anthophoridae). Entomol. Exp. Appl. 49, 181-187

Westrich P., Schmidt K. (1986) Methoden und Anwendungsgebiete der Pollenanalyse bei Wildbienen (Hymenoptera, Apoidea). Linzer Biol. Beitr. 18, 341360

Publisher's note Springer Nature remains neutral with regard to jurisdictional claims in published maps and institutional affiliations. 